\title{
Combining ability analysis for evaluation of maize hybrids under drought stress
}

\author{
Saif-ul-Malook ${ }^{*}$, Qurban Ali ${ }^{1,2}$, Muhammad Ahsan ${ }^{1}$, Muhammad Khalid Shabaz ${ }^{3}$, Muhammad Waseem ${ }^{4}$ \\ and Aamir Mumtaz ${ }^{1}$ \\ ${ }^{I}$ Department of Plant Breeding and Genetics, Faculty of Agriculture, University of Agriculture, Faisalabad, Pakistan. \\ ${ }^{2}$ Centre of Excellence in Molecular Biology, University of the Punjab, Lahore, Pakistan. \\ ${ }^{3}$ Department of Soil Science, Bahauddin Zakariya University, Multan, Pakistan. \\ ${ }^{4}$ Faculty of Agriculture, Lasbela University of Agriculture, Water and Marine Science, Uthal, Pakistan.
}

\begin{abstract}
The present study was conducted to evaluate the genetic basis of yield related traits under drought conditions. A high heritability and genetic advance was found for plant height, 100-grain weight, grain rows per cob and grain yield per plant, suggesting that the selection of high yielding maize genotypes is possible through this approach. The high specific combining ability of W64SP, A495, A509 and A50-2 suggested that the pre-screening of inbred lines may be an efficient approach to develop higher yielding maize hybrids through heterosis breeding under drought.
\end{abstract}

Keywords: Combining ability, drought, genetic advance, heritability, heterosis, Zea mays.

\section{INTRODUCTION}

Maize (Zea mays) is an important cereal crop worldwide and is ranked third after wheat and rice for its nutritional quality and uses (Cassamon, 1999; Ali et al., 2014a;b). It is a monoecious and highly cross pollinated crop mostly used as food, feed, forage, green fuel (ethanol), vegetable oil and starch and is the backbone of the poultry feed industry. Maize grain constitutes about $9.74 \%$ grain protein, $4.85 \%$ grain oil, $9.44 \%$ grain crude fibre, $71.97 \%$ grain starch, and $11.77 \%$ embryo, while fodder contains $22.98 \%$ acid detergent fibre, $51.69 \%$ neutral detergent fibre, $28.797 \%$ fodder cellulose, $40.18 \%$ fodder dry matter, $26.85 \%$ fodder crude fibre, $10.35 \%$ fodder crude protein and $9.09 \%$ fodder moisture (Ali et al., 2014 b;c; Saif-ul-Malook et al., 2014a;b;c). The Punjab region contributes to about $39 \%$ of the total area under maize cultivation with $30 \%$ of the total produce in Pakistan. The major share belongs to Sindh and KPK with $56 \%$ area and $63 \%$ production, respectively. The average production of maize in Pakistan is $3672 \mathrm{~kg} / \mathrm{ha}$, which is very low compared to other countries (Anonymous, $2012-2013)$.

Maize is affected by many biotic and abiotic factors. Drought badly affects plant growth from seedling to maturity (Areous et al., 2005) and maize is more susceptible to drought compared to the other cereals except barley (Banziger \& Araus, 2007). Drought causes reduction in leaf area, stem extension, root proliferation, low water use efficiency, metabolism, enzyme activity, ionic balance and solute accumulation (Khan et al., 1995; Farooq et al., 2002). It reduces the chlorophyll content, resulting in low photosynthesis and ultimately reductions in crop yield (Athar \& Ashraf, 2005). Water stress affects silking and extends the anthesis-silking-interval (ASI), which ultimately leads to lower crop yield (Edmeades et al., 1992). Grain yield is a quantitative trait, which depends on many factors such as plant height, plant vigour, efficient water availability, optimum nutrient availability, enhanced solar radiation interception and conversion of solar to chemical energy. The selection of a genotype for water stress is complex due to genotype interaction with the environment (Messmer, 2006; Naseem et al., $2015 \mathrm{a} ; \mathrm{b})$. The present study was conducted to evaluate the genetic basis of yield related traits under drought conditions. 


\section{METHODOLOGY}

The parents (A-495, A-509, W-64SP, W-10, A-545, A4272, A50-2, A-239) and $F_{1}$ hybrids were grown in a research field managed by the Department of Plant Breeding and Genetics, University of Agriculture Faisalabad, Pakistan. The seeds were sown at a $2.5 \mathrm{~cm}$ depth using a randomised complete block design with three replicates. The plot size was $4 \mathrm{~m}^{2}$. The plant-to-plant and row-to-row distances were 25 and $75 \mathrm{~cm}$, respectively. Data were recorded for the following traits from 10 guarded plants of each genotype: leaves per plant, leaf area, plant height, cobs per plant, grains rows per cob,100-grain weight, cob girth, grain yield per plant and cob length.

\section{Statistical analysis}

The data were analysed by using analysis of variance technique (Steel et al., 1997) to evaluate the differences in performance among the genotypes. Line $\times$ tester analysis (Kempthorn, 1957) was used to compute the combining ability effects of parents and crosses.

\section{RESULTS}

\section{Genetic components}

The heritability substantially increased and genetic advance was also high for plant height, leaf area, grain rows per cob, grain yield per plant, 100-grain weight and cob length under normal irrigated conditions (Table 1). These responses were similar under drought conditions, for which all the variables except leaf area displayed a high heritability, and leaves per plant, leaf area, grain rows per cob, cobs per plant, and 100-grain weight showed substantial genetic advance (Table 2).

Table 1: Genetic component for various agronomic traits of maize under normal irrigation conditions

\begin{tabular}{|c|c|c|c|c|c|c|c|c|c|}
\hline Traits & $\begin{array}{l}\text { Plant } \\
\text { height }\end{array}$ & $\begin{array}{l}\text { Leaves } \\
\text { per plant }\end{array}$ & $\begin{array}{c}\text { Cobs } \\
\text { per plant }\end{array}$ & $\begin{array}{l}\text { Leaf area } \\
\qquad\left(\mathrm{cm}^{2}\right)\end{array}$ & $\begin{array}{l}\text { Grain } \\
\text { rows/ }\end{array}$ & $\begin{array}{l}\text { Cob } \\
\text { girth }\end{array}$ & $\begin{array}{l}\text { Grain yield/ } \\
\text { plant }\end{array}$ & $\begin{array}{l}100 \text { grain } \\
\text { weight }\end{array}$ & $\begin{array}{c}\text { Cob } \\
\text { length }\end{array}$ \\
\hline Mean sum of squares & $380.69 * *$ & $3.63 * *$ & $1.75 * *$ & $7016.84 * *$ & $8.06 * *$ & $2.62 * *$ & $2669.31 * *$ & $179.64 * *$ & $13.39 * *$ \\
\hline Grand mean & 161.66 & 12.77 & 1.75 & 452.52 & 14.69 & 4.33 & 136.54 & 37.99 & 16.32 \\
\hline Environmental variance & 2.44 & 1.59 & 1.29 & 1224.03 & 1.67 & 1.28 & 34.91 & 2.92 & 1.95 \\
\hline Genotypic variance & 189.12 & 1.02 & 0.24 & 2896.41 & 3.19 & 0.67 & 1317.19 & 88.36 & 5.72 \\
\hline Phenotypic variance & 191.57 & 2.61 & 1.52 & 4120.43 & 4.87 & 1.95 & 1352.11 & 91.28 & 7.67 \\
\hline $\begin{array}{l}\text { Genotypic coefficient } \\
\text { of variance }\end{array}$ & 116.99 & 7.95 & 13.36 & 640.06 & 21.75 & 15.55 & 964.69 & 232.58 & 35.04 \\
\hline $\begin{array}{l}\text { Phenotypic coefficient } \\
\text { of variance }\end{array}$ & 118.49 & 20.46 & 87.00 & 910.56 & 33.12 & 45.07 & 990.27 & 240.25 & 46.99 \\
\hline Heritability $\mathrm{h}^{2}(\mathrm{bs})$ & 98.72 & 38.84 & 15.36 & 70.29 & 65.65 & 34.49 & 97.42 & 96.81 & 74.57 \\
\hline Genetic advance $\%$ & 14.84 & 8.63 & 19.02 & 17.49 & 17.29 & 19.54 & 46.04 & 42.72 & 22.21 \\
\hline
\end{tabular}

Table 2: Genetic component for various agronomic traits of maize under drought conditions

\begin{tabular}{|c|c|c|c|c|c|c|c|c|c|}
\hline Traits & $\begin{array}{l}\text { Plant } \\
\text { height }\end{array}$ & $\begin{array}{c}\text { Leaves/ } \\
\text { plant }\end{array}$ & $\begin{array}{l}\text { Cobs/ } \\
\text { plant }\end{array}$ & $\begin{array}{l}\text { Leaf } \\
\text { area }\end{array}$ & $\begin{array}{c}\text { Grain } \\
\text { rows/cob }\end{array}$ & $\begin{array}{l}\text { Cob } \\
\text { girth }\end{array}$ & $\begin{array}{l}\text { Grain yield/ } \\
\text { plant }\end{array}$ & $\begin{array}{c}\text { 100-grain } \\
\text { weight }\end{array}$ & $\begin{array}{c}\text { Cob } \\
\text { length }\end{array}$ \\
\hline Mean sum of squares & $536.66^{* *}$ & $12.96 * *$ & $16.58 * *$ & $532.12 * *$ & $42.56^{* *}$ & $38.49 * *$ & $4993.48 * *$ & $613.8 * *$ & $98.8 * *$ \\
\hline Grand Mean & 160.16 & 12.27 & 4.28 & 1.75 & 14.21 & 36.49 & 447.52 & 15.82 & 133.54 \\
\hline Environmental variance & 5.53 & 1.73 & 1.27 & 459.85 & 1.78 & 1.35 & 298.04 & 3.46 & 1.69 \\
\hline Genotypic variance & 265.56 & 5.62 & 7.65 & 18.07 & 20.39 & 18.58 & 2347.72 & 305.17 & 48.56 \\
\hline Phenotypic variance & 271.09 & 7.35 & 8.93 & 477.92 & 22.17 & 19.92 & 2645.76 & 308.63 & 50.25 \\
\hline $\begin{array}{l}\text { Genotypic coefficient } \\
\text { of variance }\end{array}$ & 165.81 & 45.75 & 178.92 & 1033.79 & 143.46 & 50.91 & 524.61 & 1928.65 & 36.36 \\
\hline $\begin{array}{l}\text { Phenotypic coefficient } \\
\text { of variance }\end{array}$ & 169.27 & 59.84 & 208.67 & 27345.51 & 155.98 & 54.59 & 591.21 & 1950.52 & 37.63 \\
\hline Heritability $\mathrm{h}^{2}$ (bs) & 97.96 & 76.46 & 85.74 & 3.78 & 91.97 & 93.24 & 88.74 & 98.88 & 96.64 \\
\hline Genetic advance $\%$ & 17.68 & 29.62 & 105.09 & 82.99 & 53.47 & 20.02 & 17.89 & 192.67 & 9 \\
\hline
\end{tabular}


Table 3: General combining ability for various agronomic traits of maize under normal conditions

\begin{tabular}{|c|c|c|c|c|c|c|c|c|c|}
\hline Parents & $\begin{array}{l}\text { Plant } \\
\text { height }\end{array}$ & $\begin{array}{c}\text { Leaves/ } \\
\text { plant }\end{array}$ & $\begin{array}{l}\text { Cobs/ } \\
\text { plant }\end{array}$ & $\begin{array}{l}\text { Leaf } \\
\text { area }\end{array}$ & $\begin{array}{c}\text { Grain } \\
\text { rows/ cob }\end{array}$ & $\begin{array}{l}\text { Cob } \\
\text { girth }\end{array}$ & $\begin{array}{c}\text { Grain } \\
\text { yield/ plant }\end{array}$ & $\begin{array}{c}\text { 100-grain } \\
\text { weight }\end{array}$ & $\begin{array}{l}\text { Cob } \\
\text { length }\end{array}$ \\
\hline A-495 & 0.87 & -0.10 & 0.062 & 1.32 & -0.99 & -0.26 & -11.36 & 3.91 & -0.31 \\
\hline A-509 & 2.68 & -0.17 & -0.21 & -11.51 & 1.14 & 0.15 & 28.15 & 1.57 & 0.77 \\
\hline W-64SP & -4.68 & 0.51 & -0.04 & 11.01 & 0.58 & 0.51 & -4.19 & -1.23 & 0.85 \\
\hline W-10 & 1.87 & -0.51 & 0.06 & -4.88 & -0.35 & -0.73 & 10.17 & -7.33 & -0.79 \\
\hline A-545 & 0.20 & 0.22 & 0.03 & 1.22 & 0.85 & 0.31 & -17.80 & -1.21 & 0.07 \\
\hline A427-2 & 1.91 & 0.31 & 0.08 & 7.41 & -1.29 & 0.36 & 4.71 & -1.03 & -0.44 \\
\hline A $50-2$ & 0.33 & -0.69 & 0.08 & -13.19 & -0.57 & -0.28 & 16.76 & 0.59 & 0.45 \\
\hline A-239 & -3.19 & 0.43 & -0.06 & 8.62 & 0.63 & -0.06 & -26.43 & 4.73 & -0.59 \\
\hline
\end{tabular}

Table 4: General combining ability for various agronomic traits of maize under drought conditions

\begin{tabular}{|c|c|c|c|c|c|c|c|c|c|}
\hline Parents & $\begin{array}{l}\text { Plant } \\
\text { height }\end{array}$ & $\begin{array}{c}\text { Leaves/ } \\
\text { plant }\end{array}$ & $\begin{array}{l}\text { Cobs/ } \\
\text { plant }\end{array}$ & $\begin{array}{l}\text { Leaf } \\
\text { area }\end{array}$ & $\begin{array}{c}\text { Grain } \\
\text { rows/ cob }\end{array}$ & $\begin{array}{l}\text { Cob } \\
\text { girth }\end{array}$ & $\begin{array}{c}\text { Grain } \\
\text { yield/ plant }\end{array}$ & $\begin{array}{l}\text { 100-grain } \\
\text { weight }\end{array}$ & $\begin{array}{c}\text { Cob } \\
\text { length }\end{array}$ \\
\hline A-495 & -0.22 & 0.04 & 0.051 & 11.49 & 0.92 & -0.26 & -11.36 & 2.88 & -0.34 \\
\hline A-509 & 0.82 & 0.12 & -0.13 & -13.33 & 0.06 & 0.15 & 23.01 & 3.54 & 0.74 \\
\hline W-64SP & 1.04 & 0.71 & -0.03 & 10.19 & 0.50 & 0.41 & -4.03 & -1.16 & 0.14 \\
\hline $\mathrm{W}-10$ & -0.72 & -0.32 & 0.07 & -4.69 & -0.42 & -0.73 & 10.16 & -7.37 & -0.32 \\
\hline A-545 & 0.14 & 0.42 & 0.06 & 1.39 & -0.82 & 0.31 & -22.82 & -2.24 & 0.04 \\
\hline A $427-2$ & -0.96 & -0.51 & 0.07 & 7.64 & -0.56 & 0.47 & 4.71 & -0.85 & -1.07 \\
\hline A $50-2$ & 0.52 & -0.50 & 0.07 & -18.70 & -0.11 & -0.29 & 21.76 & 0.52 & 1.44 \\
\hline A-239 & -0.62 & 0.03 & -0.17 & 5.99 & 0.43 & -0.06 & -21.43 & 4.68 & -0.63 \\
\hline
\end{tabular}

\section{General combining ability}

\section{Plant height (cm)}

For plant height, the highest general combining ability was found for the line A-509 (2.68), followed by W-10 (1.87) and A427-2 (1.91), while A-239 (- 3.17) and W-64SP (- 4.68) showed the lowest general combining ability under normal irrigated conditions (Table 3 ). Under drought conditions, inbred line A-509 showed the highest general combining ability, followed by W-64SP (1.04) and A50-2 (0.52), while the lowest general combining ability was found for W-10 (- 0.72) and A427-2 (- 0.96) (Table 4).

\section{Leaves per plant}

W-64SP (0.51) and A-239 (0.43) showed the highest general combining ability for leaves per plant, while the lowest general combining ability was calculated for A50-2 (- 0.69) and W-10 (-0.51) under normal irrigated conditions (Table 3). Under drought conditions, leaves per plant showed the best general combining ability for W-64SP (0.71), followed by A-545 (0.42) and A-509 (0.12), while A50-2 (0.50) and W-10 (- 0.32) showed the lowest general combining ability (Table 4 ).

\section{Leaf area $\left(\mathrm{cm}^{2}\right)$}

Leaf area under normal irrigation conditions had the highest general combining ability for W-64SP (11.01), A-239 (8.62) and A427-2 (7.41), while the lowest general combining ability was observed for A50-2 (- 13.19) and A-509 (- 11.51) (Table 3). Under drought conditions, lines A-495 (11.49), W-64SP (10.33), A-239 (5.99) and A427-2 (7.64) showed the highest general combining ability for leaf area, while the lowest was for A-509 (13.33) and A50-2 (- 18.70) (Table 4).

\section{Cobs per plant}

Genotype A-502 (0.076) (Table 3) showed the best general combining ability for cobs per plant, while A-509 (- 0.21) showed the lowest value for general combining ability under normal irrigation conditions. Inbred lines W-10 (0.07) and A50-2 (0.07) exhibited the highest general combining ability for cobs per plant, while A-239 (- 0.17) showed the lowest general combining ability under drought conditions (Table 4).

\section{Cob girth (cm)}

Inbred lines W-64SP (0.51) and A427-2 (0.36) were the best combiners while W-10 (- 0.73) and A50-2 (- 0.29) 
showed the lowest value of general combining ability under normal conditions (Table 3). Selection on the basis of cob girth may be helpful to develop high yielding genotypes under normal irrigation conditions. Under drought conditions, A427-2 (0.47) was the best general combiner and $\mathrm{W}-10$ (- 0.73$)$ was a poor general combiner (Table 4).

\section{Grain rows per cob}

For grain rows per cob, the general combining ability was the highest in A-509 (1.14) and A-545 (0.85), while A427-2 (-1.29) and A-495 (- 0.99) showed the lowest values of general combining ability under normal irrigation conditions (Table 3). Under drought conditions, inbred line A-495 (0.914) and A-239 (0.44) were the best general combiners, while A-545 (- 0.82) and A427-2 (- 0.56) showed the lowest general combining ability (Table 4).

\section{0-grain weight (g)}

The highest general combining ability effects were reported for the 100-grain weight of A-495 (3.91, 2.86), A-239 (4.73, 4.68) and A-509 (1.57, 3.54), while W-10 (- 7.33, - 7.37), A-545 (- 1.21, - 2.24) and W-64SP (- 1.21, - 1.16) exhibited the lowest general combining ability

Table 5: Specific combining ability for various agronomic traits of maize under normal conditions

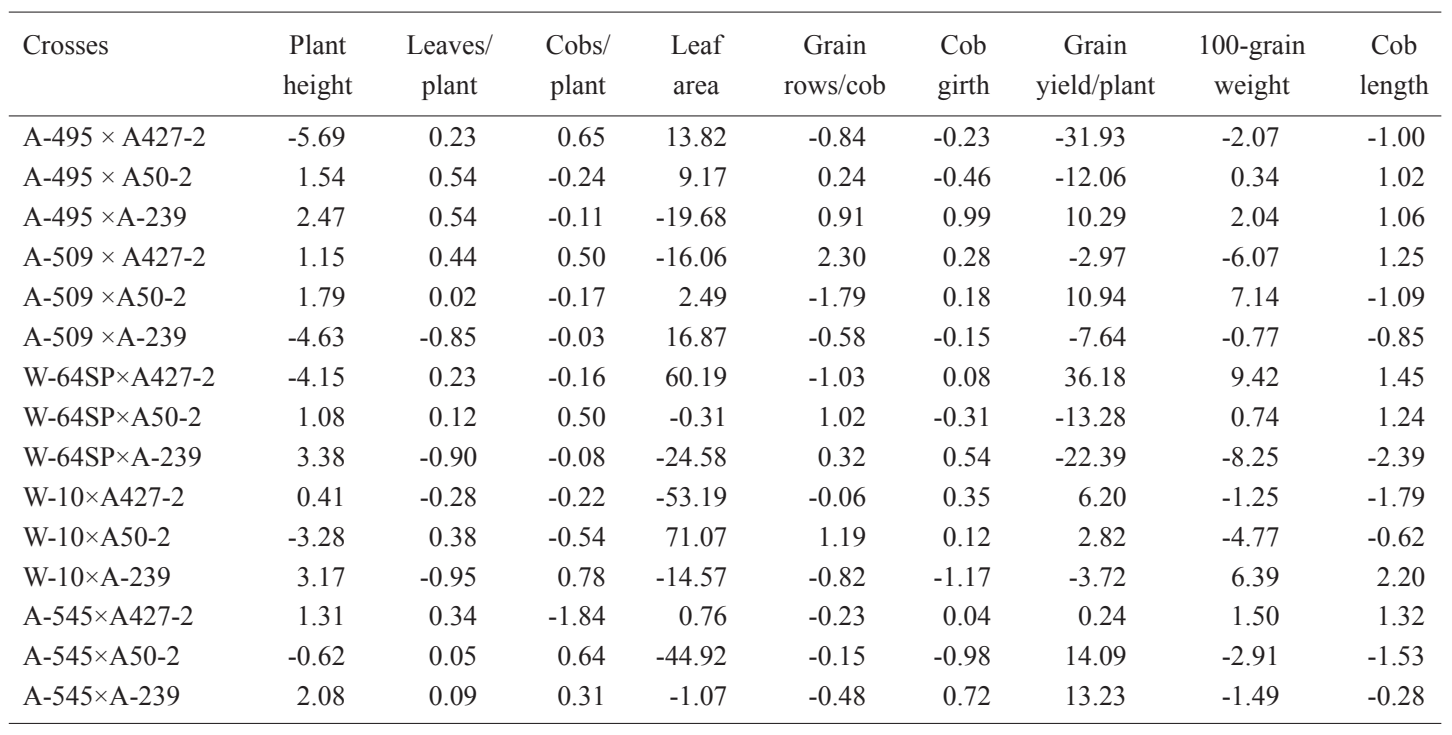

Table 6: Specific combining ability for various agronomic traits of maize under drought conditions

\begin{tabular}{|c|c|c|c|c|c|c|c|c|c|}
\hline Crosses & $\begin{array}{l}\text { Plant } \\
\text { height }\end{array}$ & $\begin{array}{c}\text { Leaves/ } \\
\text { plant }\end{array}$ & $\begin{array}{l}\text { Cobs/ } \\
\text { plant }\end{array}$ & $\begin{array}{l}\text { Leaf } \\
\text { area }\end{array}$ & $\begin{array}{c}\text { Grain } \\
\text { rows/ cob }\end{array}$ & $\begin{array}{l}\text { Cob } \\
\text { girth }\end{array}$ & $\begin{array}{c}\text { Grain } \\
\text { yield/ plant }\end{array}$ & $\begin{array}{c}\text { 100-grain } \\
\text { weight }\end{array}$ & $\begin{array}{l}\text { Cob } \\
\text { length }\end{array}$ \\
\hline A-495 $\times$ A $427-2$ & -1.07 & -0.18 & 0.66 & 13.13 & 0.001 & -0.23 & -34.93 & -1.07 & -0.77 \\
\hline $\mathrm{A}-495 \times \mathrm{A} 50-2$ & 0.21 & 0.64 & -0.31 & 7.34 & 0.24 & -0.46 & -12.06 & 1.34 & 0.02 \\
\hline $\mathrm{A}-495 \times \mathrm{A}-239$ & 0.56 & 0.92 & 0.21 & -19.24 & 0.39 & 0.99 & 34.27 & 3.04 & 0.06 \\
\hline $\mathrm{A}-509 \times \mathrm{A} 427-2$ & 2.15 & 0.01 & 0.23 & 14.23 & 2.91 & 0.28 & -2.98 & -5.07 & 0.25 \\
\hline $\mathrm{A}-509 \times \mathrm{A} 50-2$ & -0.43 & -0.18 & -0.67 & -15.23 & -2.34 & 0.18 & 13.94 & 4.14 & 0.91 \\
\hline $\mathrm{A}-509 \times \mathrm{A}-239$ & -0.46 & -1.41 & -0.19 & 25.06 & -1.34 & -0.15 & -7.65 & 0.23 & 0.12 \\
\hline $\mathrm{W}-64 \mathrm{SP} \times \mathrm{A} 427-2$ & 1.56 & 0.13 & 0.35 & 35.45 & -0.90 & 0.05 & 36.48 & 3.42 & -4.49 \\
\hline $\mathrm{W}-64 \mathrm{SP} \times \mathrm{A} 50-2$ & 2.11 & 0.11 & 0.44 & -23.23 & 0.012 & -0.32 & -13.28 & 1.24 & 2.24 \\
\hline $\mathrm{W}-64 \mathrm{SP} \times \mathrm{A}-239$ & -3.45 & -1.01 & -1.24 & -20.24 & 0.42 & 0.54 & -20.39 & -7.85 & -1.39 \\
\hline $\mathrm{W}-10 \times \mathrm{A} 427-2$ & -2.69 & 0.55 & 0.003 & -36.34 & -0.24 & 0.35 & 6.20 & -0.29 & -0.79 \\
\hline $\mathrm{W}-10 \times \mathrm{A} 50-2$ & -0.79 & -0.32 & 0.001 & 34.56 & 2.19 & 0.12 & 2.82 & -3.79 & 0.88 \\
\hline $\mathrm{W}-10 \times \mathrm{A}-239$ & 1.11 & -0.11 & -0.46 & -15.37 & -0.42 & -1.17 & -5.72 & 1.37 & 0.21 \\
\hline $\mathrm{A}-545 \times \mathrm{A} 427-2$ & 2.04 & 1.20 & 0.45 & -0.33 & -0.33 & 0.04 & 0.24 & 2.52 & 2.31 \\
\hline $\mathrm{A}-545 \times \mathrm{A} 50-2$ & -1.43 & -0.55 & 0.50 & -48.23 & 0.23 & 0.49 & 14.09 & -1.91 & -0.53 \\
\hline$A-545 \times A-239$ & 0.58 & 0.21 & 0.04 & 48.43 & -0.83 & -0.72 & -11.03 & 2.69 & 1.00 \\
\hline
\end{tabular}


under both normal and drought conditions, respectively (Tables 3 and 4). These high values of general combining ability suggested the additive effects of genes.

\section{Cob length (cm)}

The best general combining ability for cob length was recorded for A50-2 (0.45), A-509 (0.77) and W-64SP (0.85), while W-10 (- 0.79) and A-239 (- 0.59) showed the lowest under normal conditions (Table 3 ). The highest general combining ability for cob length under drought conditions was recorded for A50-2 (1.44), A-509 (0.74) and W-64SP (0.14), while the lowest was measured for W-10 (-0.32) and A427-2 (- 1.07) (Table 4).

\section{Grain yield per plant (g)}

Maximum general combining ability among the parents were reported for A-509 (28.15, 23.01), A50-2 (16.76, 21.76), W-10 (10.17, 10.17) and A427-2 (4.70, 4.71), while the lowest general combining ability was observed for A-239 (- 26.43, - 21.43), A545 (- 17.80, - 22.82) and A-495 (- 11.36, - 11.36) under normal irrigation and drought conditions, respectively (Tables 3 and 4).

\section{Specific combining ability}

\section{Plant height (cm)}

Table 5 shows that the highest specific combining ability was obtained for crosses W-10 × A427-2 (3.13), W-64SP $\times$ A-239 (3.38) and A-495 $\times$ A-239 (2.47) while the lowest specific combining ability occurred for A-495 $\times$ A427-2 (- 5.69) under normal conditions. Under drought conditions cross A-509 $\times$ A427-2 (2.15) had the highest value of specific combining ability for plant height (Table 6).

\section{Leaves per plant}

For leaves per plant (Table 5), A-495 × A50-2 (0.54) and A-495 $\times$ A-239 (0.54) showed the highest specific combining ability, which shows a higher dominance effect of genes, while the cross W-64SP $\times$ A-239 (- 0.90) showed the lowest negative specific combining ability. Table 6 indicates that the crosses A-495 × A50-2 (0.64), A-495 $\times$ A-239 (0.92) and A-545 $\times$ A427-2 (1.20) had the highest specific combining abilities, while A-509 $\times$ A-239 (- 1.41) showed the lowest specific combining ability under drought conditions.

\section{Leaf area $\left(\mathrm{cm}^{2}\right)$}

With respect to leaf area, the highest value of specific combining ability was recorded for W-10 $\times$ A50-2 (71.074), W-64SP $\times$ A427-2 (60.19) and A-509 $\times$ A-239 (16.87). The highest negative effects were observed by crosses A-545 $\times$ A50-2 (- 44.92) and W-10 $\times$ A427-2 (- 53.19) under normal conditions (Table 5). The specific combining ability was the highest for $\mathrm{W}-10$ $\times$ A50-2 (34.56), W-64SP $\times$ A427-2 (35.45), A-509 $\times$ A-239 (25.06), A-545 $\times$ A-239 (48.43), while the lowest was for A-545 $\times$ A50-2 (- 48.23) and W-10 $\times$ A427-2 (- 36.34) under drought conditions (Table 6).

\section{Cobs per plant}

The highest specific combining ability for cobs per plant (Table 5) was found for the cross A-495 × A427-2 (0.65), while A-545 × A427-2 (-1.84) showed the lowest specific combining ability under normal conditions. Under drought conditions the highest specific combining ability occurred for the cross A-495 $\times$ A427-2 (0.66), while the lowest value was observed for W-64SP $\times$ A-239 (- 1.24) and A-509 $\times$ A50-2 (- 0.67) (Table 6).

\section{Grain rows per cob}

For grain rows per cob, W-10 $\times$ A50-2 (1.19) and A-509 $\times$ A427-2 (2.31) showed the highest specific combining ability, while W-64SP $\times$ A427-2 (- 1.03) and A-509 $\times$ A50-2 (-1.79) showed the lowest specific combining ability effects under normal conditions (Table 5). Under drought conditions, A509 $\times$ A427-2 (2.91) and W-10 $\times$ A50-2 (2.19) showed the maximum specific combining ability (Table 6).

\section{Cob girth (cm)}

The highest value for specific combining ability occurred for A-495 × A-239 (0.01), while the lowest was measured for W-10 × A-239 (- 1.17) under normal conditions (Table 5). Under drought conditions, W-64SP $\times$ A-239 (0.54) showed the highest specific combining ability, while W-10 × A-239 (-1.17) showed the lowest specific combining ability (Table 6).

\section{0-grain weight (g)}

Crosses W-64SP $\times$ A427-2 (9.42), W-10 × A-239 (6.39) and A-509 $\times$ A50-2 (7.14) exhibited the highest specific combining ability, while W-64SP $\times$ A-239 (- 8.25) showed the lowest specific combining ability under normal conditions (Table 5). Cross A-509 × A50-2 (4.14) showed the highest specific combining ability, while A509 $\times$ A427-2 (- 5.07) showed the lowest value for 100-grain weight under drought conditions (Table 6). 


\section{Cob length (cm)}

For cob length the highest specific combining ability was measured for W-10 $\times$ A-239 (2.20) while the lowest was measured for W-64SP $\times$ A-239 (- 2.386) under normal conditions (Table 5). The highest specific combining ability under drought conditions was found for A-495 $\times$ A-239 (0.99), while W-10 × A-239 (- 1.17) indicated the lowest performance (Table 6).

\section{Grain yield per plant (g)}

Tables 5 and 6 shows that A-495 $\times$ A-239 (10.296, 34.265), A-509 × A50-2 (10.94, 13.94), W-64SP $\times$ A427-2 (63.18, $36.48)$ and A-545 $\times$ A50-2 (14.09, 14.01) exhibited higher specific combining abilities under normal and drought conditions, respectively. The lowest specific combining ability was recorded for A-495 $\times$ A427-2 (- 31.93, - 34.93), W-63SP $\times$ A-239 $(22.39,20.39)$ and W-64SP $\times$ A50-2 (- 13.28, - 13.28) under normal and drought conditions, respectively.

\section{DISCUSSION}

High heritability values were reported for various traits in this trial, which suggests that the selection of high yielding maize hybrids under drought conditions may be helpful to increase the maize grain yield (Tables 1 and 2). Higher genetic advance indicates that selections can be made to develop synthetic maize cultivars under drought conditions. Eagles (1982) reported that the elite lines of endosperm and embryo were of great importance as compared to the female parents in determining the differences of germination period and relative growth of maize seedlings (Nass et al., 2000). Khidse et al. (1983) have reported that the non-additive genetic effects contribute to grain size and seedling vigour traits of sorghum, viz., seedling volume, plumule length, radicle length and root/shoot fresh and dry weights of maize seedlings. Higher shoot length suggests that higher crop biomass may be produced due to more water content, and an inbred line with a higher shoot length may be selected for fodder breeding as well as for quantitative traits. Similar results have been reported by Mehdi et al. (2001). Several crosses in this trial led to substantial genetic advance, particularly under drought conditions (Tables 1 and 2). Ali and Ahsan (2015) have reported that heterosis can be used for the maintenance of germplasm and pedigree similarities among maize hybrids. Singh et al. (1998) concluded that moderate estimates of heritability and genetic advance, i.e. positive and significant genotypic correlations, were found for grain yield per plant $v s$. plant height, cob length, grains per cob, 100-seed weight and the number of cobs per plant. Similar findings were reported by Khan et al. (2014), Saeed et al. (2014) and Ali et al. (2011a; 2012; $2013 ; 2014 a$; b; 2016) for root and shoot length.

Pandey et al. (2000) reported that increasing moisture stress was the major cause of decreases in crop growth rate, leaf area, shoot dry matter, plant height and harvesting index. Nigussie and Zelleke (2001) observed that specific combining ability effects were significant for plant height, days taken to tasseling, days taken to silking and grain yield per plant. The mid parent heterosis in this trial showed a range of $-11.6-21.9 \%$ for grain yield per plant. Similar findings were reported by Ali et al. (2013; 2014a;b) and Ahsan et al. (2010). It was suggested that increased fresh shoot length, fresh root weight and decreased stomata frequency and epidermal cell size may be useful criteria for selection under drought conditions. Ali et al. (2011a) had conducted an experiment on 40 maize genotypes at seedling stage and concluded that root length, root dry weight, leaf temperature, root density and shoot dry weight were correlated at genotypic and phenotypic levels and hence may be used as selection criteria for higher yielding maize genotypes. Ali et al. (2011b) also estimated the genetic variability and the association among different seedling traits of 40 maize genotypes. It was observed that selection may be made on the basis of shoot length and shoot weight. Higher values of general combining ability suggested that the inbred lines may be used for the development of synthetic cultivars for improving grain yield under drought conditions. The higher specific combining ability suggests that the breeding programme for the development of hybrid seed production in maize may be preceded in next generations. The selection of maize genotypes on the basis of 100-grain weight, grain rows per cob, cob girth, cob length and grain yield per plant may be effective to develop synthetic and hybrids against drought (Ali et al., 2013; 2014b; d; Masood et al., 2015a;b).

\section{CONCLUSION}

Among the inbred lines that were used for the development of $\mathrm{F}_{1}$ hybrids under drought conditions, W-64SP, A-495, A-509 and A50-2 performed best for drought tolerant hybrid development.

\section{REFERENCES}

1. Ahsan M., Hussain M.M., Farooq A., Khaliq I., Farooq J., Ali Q. \& Kashif M. (2010). Physio-genetic behavior of maize seedling at water deficit conditions. Cercetări Agronomice in Moldova 2: 41 - 49.

2. Ali Q., Ahsan M., Khaliq I., Elahi M., Shahbaz M., Ahmed W. \& Naees M. (2011a). Estimation of genetic association 
of yield and quality traits in chickpea (Cicer arietinum L.). International Research Journal of Plant Sciences 2: 166 - 169.

3. Ali Q., Elahi M., Ahsan M., Tahir M.H.N. \& Basra S.M.A. (2011b). Genetic evaluation of maize (Zea mays L.) genotypes at seedling stage under moisture stress. International Journal for Agro Veterinary Medical Sciences 5(2): $184-193$.

DOI: http://dx.doi.org/10.5455/ijavms.20110608051727

4. Ali Q., Ahsan M., Tahir M.H.N. \& Basra S.M.A. (2012). Genetic evaluation of maize (Zea mays L.) accessions for growth related seedling traits. International Journal for Agro Veterinary Medical Sciences 6: 164 - 172.

5. Ali Q., Ahsan M., Ali F., Aslam M., Khan N.H., Munzoor M., Mustafa H.S.B. \& Muhammad S. (2013). Heritability, heterosis and heterobeltiosis studies for morphological traits of maize (Zea mays L.) seedlings. Advancements in Life Sciences 1(1): $52-63$.

6. Ali Q., Ali A., Ahsan M., Ali S., Khan N.H., Muhammad S., Abbas H.G., Nasir I.A. \& Husnain T. (2014a). Line $\times$ tester analysis for morpho-physiological traits of Zea mays L. seedlings. Advancements in Life Sciences 1(4): 242 253.

7. Ali Q. et al. (15 authors) (2014b). Combining ability analysis for various physiological, grain yield and quality traits of Zea mays L. Life Science Journal 11(8s): 540 551.

8. Ali Q. et al. (14 authors) (2014c). Gene action for various grain and fodder quality traits in Zea Mays. Journal of Food and Nutrition Research 2(10): $704-717$.

DOI: http://dx.doi.org/10.12691/jfnr-2-10-9

9. Ali Q., Ali A., Waseem M., Muzaffar A., Ahmad S., Ali S., Awan M.F., Samiullah T.R., Nasir I.A. \& Tayyab H. (2014d). Correlation analysis for morpho-physiological traits of maize (Zea mays L.). Life Science Journal 11(12s): 9- 13.

10. Ali Q. \& Ahsan M. (2015). Correlation analysis for various grain contributing traits of Zea mays. African Journal of Agricultural Research 10(23): 2350 - 2354. DOI: http://dx.doi.org/10.5897/AJAR2013.7838

11. Ali Q., Ahsan M., Saif-ul-Malook, Kanwal N., Ali F., Ali A., Ahmed W., Ishfaq M. \& Saleem M. (2016). Screening for drought tolerance: comparison of maize hybrids under water deficit condition. Advancements in Life Sciences 3(2): $51-58$.

12. Anonymous (2012 - 2013). Economic Survey of Pakistan. Ministry of Finance, Government of Pakistan, Economic Advisor's Wing, Islamabad, Pakistan.

13. Areous L., Slafer G., Royo C. \& Serret M.D. (2005). Breeding for yield potential and stress adaptation in cereals. Critical Reviews in Plant Sciences 27: 377 - 412. DOI: http://dx.doi.org/10.1080/07352680802467736

14. Athar H.R. \& Ashraf M. (2005). Photosynthesis under drought stress. Handbook of Photosynthesis (ed. M. Pessarakli), pp. 793 - 804. CRC Press, New York, USA.

15. Banziger M. \& Araus J.L. (2007). Recent advances in breeding maize for drought and salinity stress tolerance.
Advances in Molecular Breeding toward Drought and Salt Tolerant Crops (eds. M.A. Jenks, P.M. Hasegawa \& M.S. Jain), pp. 587 - 601. Springer, The Netherlands.

DOI: http://dx.doi.org/10.1007/978-1-4020-5578-2_23

16. Cassamon K.G. (1999). Ecological intensification of cereal production systems, yield potential, soil quality, and precision agriculture. Proceedings of the National Academy of Sciences of the USA 96: 5952 - 5959.

DOI: http://dx.doi.org/10.1073/pnas.96.11.5952

17. Eagles H.A. (1982). Inheritance of emergence time and seedling growth at low temperatures in four lines of maize. Theoretical and Applied Genetics 62: $81-87$.

18. Edmeades G.O., Bolanos J., Hernadez M. \& Bello S. (1992). Causes for silk delay in lowland tropical maize population. Crop Science 33: 1029 - 1035.

19. Farooq M., Wahid A., Cheema S.A., Lee D.J. \& Aziz T. (2002). Comparative time course action of foliar applied glycinebetaine, salicylic acid, nitrous oxide, brasinosteroids and spermine in improving drought resistance of rice. Journal of Agronomy and Crop Sciences 196: 336 - 345. DOI: http://dx.doi.org/10.1111/j.1439-037X.2010.00422.x

20. Kempthorn O. (1957). An Introduction to Genetic Statistics, p. 545. John Wiley and Sons Inc., New York, USA.

21. Khan N.H., Ahsan M., Saleem M. \& Ali A. (2014). Genetic association among various morpho-physiological traits of Zea mays under drought. Life Science Journal 11(10s): 112 - 122.

22. Khan M.A., Akbar S., Ahmad K., Baloch M.S. \& Sadiq M. (1995). Evaluation of corn hybrids for grain yield in D.I. Khan. Pakistan Journal of Biological Sciences 2: 413 - 414.

23. Khidse S.R., Bhall N.L. \& Borikar S.T. (1983). Combining ability for seedling vigour in sorghum. Journal of Maharashtra Agriculture University 8: 59-60.

24. Masood S.A., Sofia J., Madiha A., Zain N., Anum J. \& Ali Q. (2015a). Genetic association of transcriptional factors (OsAP2 gene family) to incorporate drought tolerance in rice (Oryza sativa L. ssp. indica): an overview. Life Science Journal 12(3s): $71-76$.

25. Masood S.A., Zain N., Madiha A., Arshad S., Anum J., Samad A. \& Ali Q. (2015b). An overview of genetic improvement for drought tolerance in rice (Oryza sativa). Life Science Journal 12(3s): 63 - 70.

26. Mehdi S.S., Ahmad N. \& Ahsan M. (2001). Evaluation of S1 maize (Zea mays L.) families at seedling stage under drought conditions. Online Journal of Biological Sciences 1: $4-6$. DOI: http://dx.doi.org/10.3923/jbs.2001.4.6

27. Messmer R.E. (2006). The genetic dissection of key factors involved in the drought tolerance of tropical maize (Zea mays L.), PhD thesis, Swiss Federal Institute of Technology Zurich, Zurich, Switzerland.

28. Naseem Z., Masood S.A., Irshad S., Annum N., Bashir M.K., Anum R., Qurban A., Arfan A. \& Naila K. (2015a). Critical study of gene action and combining ability for varietal development in wheat: an overview. Life Science Journal 12(3s): $104-108$. 
29. Naseem Z., Masood S.A., Ali Q., Ali A. \& Kanwal N. (2015b). Study of genetic variability in Helianthus annuus for seedling traits: an overview. Life Science Journal 12(3s): 109 - 114.

30. Nass L., Lima L., Vencovsky M. \& Cruz R. (2000). Combining ability of maize inbred lines evaluated in three environments in Brazil. Scientia Agrícola Piracicaba 57: $129-134$.

DOI: http://dx.doi.org/10.1590/S0103-90162000000100021

31. Nigussie M. \& Zelleke H. (2001). Heterosis and combining ability in a diallel among eight elite maize populations. African Journal of Crop Sciences 9: 471 - 479.

DOI: http://dx.doi.org/10.4314/acsj.v9i3.27593

32. Pandey R.K., Maranville J.W. \& Chetima M.M. (2000). Deficit irrigation and nitrogen effects on maize in a Sahelian environment II. shoot growth, nitrogen uptake and water extraction. Agriculture Water Management 46: 15 - 27.

33. Saeed A., Nadeem H., Amir S., Muhammad F.S., Nazar H.K., Khurram Z., Rana A.M.K. \& Nadeem S.
(2014). Genetic analysis to find suitable parents for development of tomato hybrids. Life Science Journal 11(12s): $30-35$.

34. Saif-ul-malook, Ahsan M., Ali Q. \& Mumtaz A. (2014a). Genetic variability of maize genotypes under water stress and normal conditions. Researcher 6: $31-37$.

35. Saif-ul-malook, Ahsan M., Ali Q. \& Mumtaz A. (2014b). Inheritance of yield related traits in maize under normal and drought condition. Nature and Science 12: 36 - 49.

36. Saif-ul-malook, Ali Q., Muhammad A., Aamer M. \& Muhammad S. (2014c). An overview of conventional breeding for drought tolerance in Zea mays. Nature and Science 12: 7 - 22 .

37. Singh A.K., Shahi J.P., Singh J.K. \& Singh R.N. (1998). Heritability and genetic advance for maturity and yield attributes in maize. Journal of Applied Biology 8: 42 - 45.

38. Steel R.G.D., Torrie J.H. \& Dicky D.A. (1997). Principles and Procedures of Statistics: A Biometrical Approach, $3^{\text {rd }}$ edition, pp. 400 - 428. McGraw Hill Book Co. Inc., New York, USA. 